Martin, R. G. (1963). F. biol. Chem. 238, 257.

Monod, J. (1942). Recherches sur la Croissance des Cultures Bactériennes. Paris: Hermann et Cie.

Monod, J., Changeux, J.-P. \& Jacob, F. (1963). 7. mol. Biol. 6, 306.

Moyed, H. S. (1960). F. biol. Chem. 235, 1098.

Moyed, H. S. \& Umbarger, H. E. (I 962). Physiol. Rev. 42, 444.

Nara, 'T., Samijema, H., Fugita, G., Ito, M., Nakayama, K. \& Kinoshita, S. (I 961). Agric. biol. Chem., Tokyo, 25, 532 .

Neidhardt, F. C. \& Fraenkel, D. G. ( I961). Cold Spr. Harb. Symp. quant. Biol. 26, 63.

Neidhardt, F. C. \& Magasanik, B. (1956). Nature, Lond., 178, 801.

Neidhardt, F. C. \& Magasanik, B. (1957). F. Bact. 73, 253.

Pardee, A. B. \& Prestidge, L. S. (196r). Biochim. biophys. Acta, 49, 77.

Patte, J.-C., Le Bras, G., Loviny, T. \& Cohen, G. N. (1963). Biochim. biophys. Acta, 67 , 16.

Patte, J.-C., Loviny, T. \& Cohen, G. N. (I962). Biochim. biophys. Acta, 58, 359.

Pichinoty, F. ( I 962). Biochim. biophys. Acta, 64, I I I.

Pizer, L. I. (1963). F. biol. Chem. 238, 3934 .

Roberts, R. B., Cowie, D. B., Abelson, P. H., Bolton, E. T. \& Britten, R. J. (1955). Publ. Carneg. Instn, no. 607 .

Rowbury, R. J. (1962). Biochem. $\mathscr{F} .82,24 \mathrm{P}$.

Rowbury, R. J. \& Woods, D. D. (I961). F. gen. Microbiol. 24, I 29.

Schaechter, M., Maaløe, O. \& Kjeldgaard, N. O. (1958). F. gen. Microbiol. 19, 592.

Shepherdson, M. \& Pardee, A. B. (1960). F. biol. Chem. 235, 3233.

Smith, R. A. \& Gunsalus, I. C. (1957). F. biol. Chem. 229, 305.

Snell, E. E. (1943). Arch. Biochem. 2, 389 .

Stadtman, E. R., Cohen, G. N., LeBras, G. \& de Robichon-Szulmajster, H. (ig6r). F. biol. Chem. 236, 2033 .

Stent, G. S. \& Brenner, S. (I961). Proc. nat. Acad. Sci., Wash., 47, 2005.

Udaka, S. \& Kinoshita, S. (1958). F. gen. appl. Microbiol. 4, 283.

Umbarger, H. E. (1956). Science, 123, 848 .

Umbarger, H. E. (1960). Fed. Proc. 19, 52.

Umbarger, H. E. (г96г). Cold Spr. Harb. Symp. quant. Biol. 26, зог.

Umbarger, H. E. \& Brown, B. (1957). F. Bact. 73, 105.

Umbarger, H. E. \& Brown, B. (1958a). F. biol. Chem. 233, 415.

Umbarger, H. E. \& Brown, B. (1 $958 b$ ). $\%$. biol. Chem. 233, I 56 .

Vogel, H. J. (1957). In The Chemical Basis of Heredity, p. 276. [W. D. McElroy and B. Glass, editors.] Baltimore, Md: Johns Hopkins Press.

Vogel, H. J. (I96r). Cold Spr. Harb. Symp. quant. Biol. 26, 163.

Wijesundera, S. \& Woods, D. D. (1953). Biochem. F. 55, viii.

Wimpenny, J. W. T., Ranlett, M. \& Gray, C. 'T. (1963). Biochim. biophys. Acta, 73, ı 70.

Wormser, E. H. \& Pardee, A. B. (1958). Arch. Biochem. Biophys. 78, 416.

Yates, R. A. \& Pardee, A. B. (1956). F. biol. Chem. 221, 757.

\title{
The nutrition of certain intestinal protozoa
}

\section{By J. Margaret Eadie, Rowett Research Institute, Bucksburn, Aberdeen}

The nutritional requirements of some of the free-living protozoa, such as members of the genus Tetrahymena, are now well understood (Kidder \& Dewey, 1951), but the nutrition of certain non-free-living protozoa still presents many problems. The object of this review is to consider Entamoeba histolytica or the 'dysentery amoeba' whose habitat is the large intestine of man, and the rumen ciliate protozoa which are normally found in considerable numbers in the first compartment of the stomach of ruminants.

The nutrition of $E$. histolytica is of importance in relation to the pathogenic effect of the organism. The study of rumen ciliate nutrition, however, has been stimulated by consideration of possible beneficial contributions to the nutrition of the host. The products of rumen ciliate metabolism are passed on to the host either directly or after further breakdown by rumen bacteria and the effect of the ciliates upon the 
ingested food is of significance. The damage caused to the host by $E$. histolytica is not due to the removal of food material or to the products of its metabolism but rather to the direct effect of the organisms upon the host tissues when these are invaded.

There has been considerable controversy over the terms which should be used to describe the mode of nutrition of these two types of protozoa. On the one hand, is E. histolytica in fact an obligatory tissue invader and parasite-as its specific name implies - or can it remain a commensal living on bacteria and detritus in the intestine (Hoare, I958)? On the other hand, are the rumen ciliates merely commensals or can they justifiably be termed symbionts because of distinct contributions to the host's digestion? These questions are not as easy to answer as one might expect.

Early studies of $E$. histolytica have been adequately reviewed by Lwoff (I95I), Nakamura (1953), Porter (1953) and Balamuth \& Thompson (1955). Both Oxford (I955) \& Hungate (I955) reviewed the earlier work with rumen ciliates and Coleman (1963) and Eadie \& Howard (1963) have considered some more recent progress. It would be impossible to cover all aspects of the subject, but possibly the complexities of the ecology and nutrition of these two types of protozoa of the alimentary canal can best be illustrated by discussion of some of the varied experimental approaches to the problems.

\section{Nutrition of $E$. histolytica}

Direct microscopic examinations of faecal samples from patients suffering from dysentery have shown that many of the trophozoites, or actively feeding forms of the organism, contain ingested red blood cells. However, only $80 \%$ of infected human hosts show serious symptoms and Hoare (1952) reported that $30-100 \%$ of the organisms he examined from chronic cases showed ingested bacteria but no erythrocytes. He considered these commensal organisms to be the typical form of $E$. histolytica. Post-mortem examination has shown that where tissue damage does occur it is most frequent at the least active regions of the large intestine. Liver abscesses also occur, and in this site the amoebae are not found in association with bacteria. Resistant cysts are formed by the commensal trophozoites and these initially contain storage glycogen which gradually disappears before excystation.

It would be difficult to obtain reasonable numbers of amoebae from a healthy host, so that cultures have been essential for most work with $E$. histolytica.

Boeck \& Drbohlav (I925) first maintained an actively growing culture on a biphasic medium consisting of coagulated egg slants overlayed with serum and Locke's solution. A mixed bacterial flora was also present. Dobell \& Laidlaw (I926) discovered that rice starch stimulated amoebal growth in the culture. The components of the medium were not based on knowledge of the natural environment of the organisms. Very little carbohydrate would be expected in the contents of the large intestine, and Welch, Wakefield \& Adams (1936) found that only $5 \%$ of the dietary carbohydrate intake had reached that organ in a patient with ileostomy. Nevertheless, the initial choice of culture medium components was fortunate since Balamuth $\&$ Howard (I946) later showed that rice starch promoted amoebal growth and did $23(2) 6$ 
not merely promote growth of the bacteria in the culture, and the importance of cholesterol was indicated by Rees, Bozicevich, Reardon \& Daft (1944).

Hopkins \& Warner ( I 946) examined the feeding habits of cultured amoebae microscopically and observed the ingestion of rice starch and its subsequent digestion during passage through the organism. Bacteria, fat globules and yeast were ingested with some degree of selection. Trophozoites in heavy cultures were observed by Cleveland \& Sanders ( 1930) to ingest cysts of their own species. These workers also noted that cysts from cultures containing rice flour showed more storage glycogen than those obtained directly from the host.

After the successful culture of amoebae along with a mixed bacterial flora, attempts were made to reduce the bacterial population and develop monoxenic cultures. Rees and co-workers, who removed bacteria from the initial inoculum by washing the cysts, developed a monoxenic culture with a single bacterial species termed 'organism t' (Rees, 1942; Rees, Bozicevich, Reardon \& Jones, 1942). Antibiotics became of great value. Shaffer \& Frye (r948) cultured the amoebae along with a viable but penicillin-inhibited Streptobacillus, Bacteroides symbiosus. Jacobs ( 1947 ) did not obtain very good growth in cultures in which he had reduced the activity of the associated bacterium Escherichia coli by heat treatment, but much more recently Reeves, Schweinfurth \& Frye (I 960) maintained the amoebae along with B. symbiosus which had been rendered incapable of further growth and reproduction by irradiation. The irradiated cells were readily ingested by the amoebae. However, ingestion of the bacterium does not necessarily indicate the success of a culture. In certain successful cultures with penicillin-inhibited bacterial cells the amoebae only ingested so-called 'round bodies' (protoplasts) produced by the bacteria on treatment with penicillin, whereas in some unsuccessful cultures the amoebae were seen to ingest the whole bacterium (Shaffer, Key \& McDade, I960).

Phillips (1950) developed another form of monoxenic culture by substituting the flagellate Trypanosoma cruzi for B. symbiosus. The initial bacteria were removed with penicillin. Microcultures with heat-treated trypanosomes also survived, but Nakamura \& Anderson (195I) have since indicated that the flagellates could still respire.

Another approach to the culture of amoebae with living cells was that of Shaffer \& Sienkiewicz (1952) who kept amoebae in association with chick embryo tissue. They noted that the action of the amoebae when invading the tissue appeared to be merely mechanical. Other workers have reported some progress in culturing the amoebae with ground-up embryo tissue (Baernstein, Rees \& Bartgis, 1957).

While workers continued to search for a medium which would support the amoebae without a living associate, the biochemical activities of the organisms, and in particular the carbohydrate utilization, were studied. Hallman \& DeLamater (1953) demonstrated that an amylolytic substance would diffuse from amoebae grown on a soluble starch-agar medium. The bacterial flora grown alone proved less active. After twenty transfers in media without starch the activity was still present. In Warburg studies Entner \& Anderson (1954) noted that lactic and succinic acids were produced by resting trophozoites of two strains, but the addition of glucose had a more pronounced effect in stimulating acid production if glucose had been present 
in the original culture medium. Experiments with ${ }^{14} \mathrm{C}$-labelled glucose have resulted in recovery of labelled glycogen (Becker \& Geiman, I955), but Seaman (r963) states that Entner has again observed strain differences related to the carbohydrate in the original medium. Various sugars have been found to stimulate the production of $\mathrm{CO}_{2}$ and $\mathrm{H}_{2} \mathrm{~S}$ by washed suspensions of amoebae in the presence of cysteine (Kun, Bradin \& Dechary, 1956). Entner \& Hall (1955), when studying the effect of adding glucose and maltose to suspensions, noted that the sum of the activities of the amoebae and bacteria examined separately differed from that of an equivalent mixture. This finding indicates some interaction between the two organisms living in association.

An interesting insight into the relationship between the amoebae and bacteria in vivo rather than in vitro was given by experiments using gnotobiotic guinea-pigs (Phillips, Wolfe, Rees, Gordon, Wright \& Reyniers, 1955). Following reports of the apparent removal of amoebae from hosts treated with bactericidal agents known to have no direct effect on the amoebae (Armstrong, Wilmot \& Elsdon-Dew, 1950), Phillips et al. (I955) examined the effect upon guinea-pig hosts of amoebae alone and amoebae plus bacteria. Virulent strains of amoebae grown with $T$. cruzi were inoculated into completely germ-free and conventional animals. In addition the same inoculum was given to animals previously inoculated with a culture of a bacterium known to support amoebal growth in monoxenic culture: B. symbiosus, E. coli, and Aerobacter aerogenes were used. The results were convincing. The germ-free animals never showed any sign of amoebiasis, trophozoites were not seen after the $5^{\text {th }}$ day and the intestine wall of these animals appeared completely normal histologically. The conventional animals were severely damaged and almost $50 \%$ died from amoebiasis. Both $E$. coli and $A$. aerogenes grew well in the guinea-pigs and there were clear pathogenic signs in these animals. B. symbiosus did not grow well and there were no pathological signs, though the life of the amoebae may have been extended. These experiments seem to indicate that under natural conditions the presence of bacteria is essential for the tissue invasion and pathogenicity of the amoebae and also for the establishment of a commensal population.

The biochemical studies have illustrated some of the hazards of using varied cultures incorporating living associates. Fortunately Diamond (196I) developed a truly axenic culture for certain strains of $E$. histolytica. He has since reported difficulty in culturing other strains on this medium (Diamond, 1962), but it seems likely that previous in vitro treatment has caused these differences. The medium contained a number of undefined components such as yeast, serum and embryo extract. The next step will be to follow up the work of Balamuth \& Kawakami (1963) for the closely related reptilian parasite Entamoeba invadens and replace unknown by defined components as a step towards determination of the nutritional requirements of the organism. When this has been achieved for $E$. histolytica then many questions of its metabolism and nutrition will be solved.

The nutrition of the rumen ciliate protozoa

Rumen ciliate culture is at a far less advanced state than that of E. histolytica 
despite the apparent advantage of ready access to the natural environment of the organisms. Coleman ( 1960 ) maintained species of the genus Entodinium in a culture medium containing dried grass, rumen fluid and rice starch, all of which were essential. In addition, chloramphenicol was necessary to keep down the growth of associate bacteria and prevent them from overpowering the ciliates. Mah (1963) and Clarke (1963) have also maintained non-axenic cultures for some time, but again the components of the medium have been complex and have included solid materials. Some biochemical studies of organisms from these cultures have been carried out (Mah, I963; Bailey \& Clarke, 1963). Quinn and his colleagues have attempted to grow mixed rumen ciliates on a defined medium (Quinn, Burroughs \& Christiansen, I 962). They used a complex continuous culture apparatus with built-in oxidation-reduction potential and $\mathrm{pH}$ control systems (Quinn, r962). Unfortunately the apparatus has not been run for longer than 7 days.

Since rumen fluid can be obtained from a healthy host by stomach tube or rumen fistula, cultures are not so vital as for the study of $E$. histolytica. Heald, Oxford \& Sugden (1952) developed a method for separating the ciliates from rumen fluid, and modifications of this method have been used to prepare suspensions and cell-free extracts which, for short-term experiments, are virtually bacteria-free. Rumen ciliates throughout the world have given consistent and reproduceable results. Variations, if present, would most probably depend, not on the culture method as with $E$. histolytica, but on the diet of the host. A ciliate population may be almost eliminated if a high proportion of starch is given to the animals. The cause is acid production by starch-degrading bacteria which leads to a rumen $\mathrm{pH}$ too low to support the ciliates (Eadie, I962a). These changes illustrate the interrelationship between the rumen flora and fauna.

Observations of the material ingested or utilized by rumen ciliates have been made. Species of the genera Isotricha and Dasytricha can utilize various soluble sugars and form amylopectin storage granules (Oxford, I95 I). Isotricha species will also ingest small starch granules, and empty organisms have been seen to ingest bacteria (Gutierrez, I 958). These organisms, however, will not ingest suspensions of their own storage material (Howard, 1959a). Selective ingestion of bacteria has been observed in several Ophryoscolecid ciliates by Gutierrez \& Davis (1959). Plant particles, plant fibres, ground cellulose, casein or soya-bean meal have been seen to be ingested by a range of other species.

Since the ciliate activity is so varied, it would be difficult to study the biochemistry of individual species starting with mixed suspensions. However, a method of maintaining chosen species in separate sheep has been devised; since rumen ciliates do not produce resistant cysts, transfer of organisms can be prevented by spatial isolation of the host (Eadie, I962a).

The carbohydrate-hydrolysing enzymes of a number of separate ciliate species have been studied (Howard, r959a,b; Abou Akkada \& Howard, I960). As noted by Howard ( 1963 ), all rumen ciliates so far examined produce volatile fatty acids, carbon dioxide and hydrogen as products of carbohydrate fermentation, and they all form starch when fermenting an ample supply of substrate. 
Cell-free extracts and washed suspensions of active organisms were also used to examine the nitrogen metabolism of Entodinium caudatum (Abou Akkada \& Howard, 1962). Both acted upon casein to give peptides and amino acids, the chief endogenous excretory product was ammonia, and urea was neither utilized nor produced. Coleman ( $\mathrm{r}_{963}$ ) reported the uptake of ${ }^{14} \mathrm{C}$-labelled glycine by this species, and the uptake of ${ }^{14} \mathrm{C}$-labelled leucine, alanine and valine was demonstrated for a species of the genus Ophryoscolex by Williams, Davis, Doetsch \& Gutierrez (196r).

Whether the rumen ciliates that are seen to ingest plant fibres can break down cellulose has long been a controversial problem. Recently the presence of an active cellulase has been demonstrated in cell-free extracts of Polyplastron multivesiculatum. Control experiments indicated that the effect of any bacteria still present in the extract had been negligible (Abou Akkada, Eadie \& Howard, I963). A xylanase and hemi-cellulase have been found in Epidinium ecaudatum, but there was no cellulase activity. Unlike $P$. multivesiculatum, however, this organism does not ingest large plant fibres (Bailey, Clarke \& Wright, I962).

The utilization of lipids by rumen ciliates has as yet received little attention. However, Gutierrez and associates have shown that washed suspensions of both species of Isotricha and Entodinium simplex were capable of assimilating ${ }^{14} \mathrm{C}$-labelled stearic, oleic, linoleic and palmitic acids and of effecting hydrogenation of oleic acid and linoleic acid to yield stearic acid; hydrolysis of tributyrin has been demonstrated in Isotricha intestinalis (Gutierrez, Williams, Davis \& Warwick, I962; Williams, Gutierrez \& Davis, I963).

Axenic cultures are necessary before the problems of the nitrogen metabolism and growth of rumen ciliates can be effectively studied. In addition, the relationship between the rumen bacteria and protozoa is still not clear. Animals may be kept completely ciliate-free, and Eadie \& Hobson (1962) have shown that the bacterial count in such an animal drops when ciliates are established. Since rumen bacteria and ciliates have similar biochemical capabilities, this may be evidence of an ecological balance effect and may not mean that large numbers of bacteria have been ingested by the ciliates.

A further form of nutrition in rumen ciliates has been examined in attempts to trace the cause of the irreversible changes in ciliate population noted by Eadie $(1962 b)$. With the aid of a modification of the in vivo culture technique of Fina, Keith, Bartley, Hartman \& Jacobson ( 1962 ), both predation and cannibalism have been observed in $P$. multivesiculatum. However, the reason why some species should be completely removed from a population while others continue to thrive is still a mystery.

\section{Conclusion}

The foregoing discussion of studies of both $E$. histolytica and the rumen ciliates has illustrated some of the complexities of the organisms themselves. In addition attention has been drawn to the many and varied factors that may influence the nutrition of organisms living, not only in close association with the host, but also in close association with the other micro-organisms that share the same habitat. 


\section{REFERENCES}

Abou Akkada, A. R. \& Howard, B. H. (1960). Biochem. F. 76, 445.

Abou Akkada, A. R. \& Howard, B. H. (1962). Biochem. F. 82, 313.

Abou Akkada, A. R., Eadie, J. M. \& Howard, B. H. (1963). Biochem. F. 89, 268.

Armstrong, T. G., Wilmot, A. J. \& Elsdon-Dew, R. (r950). Lancet, ii, ro.

Baernstein, H. D., Rees, C. W. \& Bartgis, I. L. (1 957). F. Parasit. 43, 143.

Bailey, R. W. \& Clarke, R. 'T. J. (I963). Nature, Lond., r99, I29I.

Bailey, R. W., Clarke, R. T. J. \& Wright, D. E. (1962). Biochem. F. 83, 517.

Balamuth, W. \& Howard, B. (1946). Amer. F. trop. Med. 26, 77 I.

Balamuth, W. \& Kawakami, T. (1963). F. Parasit. 49, suppl., p. 6 r.

Balamuth, W. \& Thompson, P. E. (1955). In Biochemistry and Physiology of Protozoa. Vol. 2, p. 277.

[S. H. Hutner \& A. Lwoff, editors.] New York: Academic Press Inc.

Becker, C. E. \& Geiman, Q. M. (1955). Exp. Parasit. 4, 493.

Boeck, W. C. \& Drbohlav, J. (1925). Amer. F. Hyg. 5, 371.

Clarke, R. T. J. (1963). F. gen. Microbiol. 33, 401.

Cleveland, L. R. \& Sanders, E. P. (1930). Arch. Protistenk. 70, 223.

Coleman, G. S. (1960). F. gen. Microbiol. 22, 555 .

Coleman, G. S. (1963). Symp. Soc. gen. Microbiol. 13, 298.

Diamond, L. S. (r 96r). Science, 134, 336.

Diamond, L. S. (1962). Y. Parasit. 48, suppl., p. 39

Dobell, C. \& Laidlaw, P. P. (1926). Parasitology, 18, 28j.

Eadie, J. M. (1962a). \%. gen. Microbiol. 29, 563

Eadie, J. M. (1962b). 7. gen. Microbiol. 29, 579.

Eadie, J. M. \& Hobson, P. N. (1962). Nature, Lond., 193, $5 \circ 3$.

Eadie, J. M. \& Howard, B. H. (1963). In Progress in Nutrition and Allied Sciences, p. 57. [D. P. Cuthbertson, editor.] Edinburgh: Oliver \& Boyd.

Entner, N. \& Anderson, H. H. (1954). Exp. Parasit. 3, 234.

Entner, N. \& Hall, N. C. (1955). Exp. Parasit. 4, 92.

Fina, L. R., Keith, C. L., Bartley, E. E., Hartman, P. A. \& Jacobson, N. L. (1962). F. Anim. Sci. 21, 930.

Gutierrez, J. (1958), \%. Protozool. 5, 122.

Gutierrez, J. \& Davis, R. E. (1959). F. Protozool. 6, 222.

Gutierrez, J., Williams, P. P., Davis, R. E. \& Warwick, E. J. (1962). Appl. Microbiol. ro, 548.

Hallman, F. A. \& DeLamater, J. N. (1953). Exp. Parasit. 2, I7o.

Heald, P. J., Oxford, A. E. \& Sugden, B. (1952). Nature, Lond., 169, 1055.

Hoare, C. A. (1952). Parasitology, 42, 43.

Hoare, C. A. (1958). Rice Inst. Pamphl. 45, 23.

Hopkins, D. L. \& Warner, K. L. (1946). F. Parasit. 32, 175.

Howard, B. H. (1959a). Biochem. F. 71, 671.

Howard, B. H. (1959b). Biochem. F. 7x, 675.

Howard, B. H. (1963). Biochem. F. 89, 89 P.

Hungate, R. E. (1955). In Biochemistry and Physiology of Protozoa. Vol. 2, p. I59. [S. H. Hutner and A. Lwoff, editors.] New York: Academic Press Inc.

Jacobs, L. (1947). Amer. F. Hyg. 46, i 72.

Kidder, G. W. \& Dewey, V. C. (195I). In Biochemistry and Physiology of Protozoa. Vol. I, p. 324. [A. Lwoff, editor.] New York: Academic Press Inc.

Kun, E., Bradin, J. L. Jr. \& Dechary, J. M. (1956). Biochim. biophys. Acta, 19, I 53.

Lwoff, M. (I951). In Biochemistry and Physiology of Protozoa. Vol. 1, p. 235. [A. Lwoff, editor.] New York: Academic Press Inc.

Mah, R. A. (1963). Bact. Proc. p. 9.

Nakamura, M. (1953). Bact. Rev. 17, 189.

Nakamura, M. \& Anderson, H. H. (I951). Amer. F. trop. Med. 31, 438.

Oxford, A. E. (195 I). 7. gen. Microbiol. 5, 83.

Oxford, A. E. (1955). Exp. Parasitol. 4, 569.

Phillips, B. P. (1950). Science, III, 8.

Phillips, B. P., Wolfe, P. A., Rees, C. W., Gordon, H. A., Wright, W. H. \& Reyniers, J. A. (I955). Amer. F. trop. Med. Hyg. 4, 675.

Porter, R. J. (1953). Annu. Rev. Microbiol. 7, 273.

Quinn, L. Y. (1962). Appl. Microbiol. 10, 580.

Quinn, L. Y., Burroughs, W. \& Christiansen, W. C. (1962). Appl. Microbiol. 10, 583.

Rees, C. W. (1942). Amer. F. trop. Med. 22, 487.

Rees, C. W., Bozicevich, J., Reardon, L. V. \& Daft, F. S. (1944). Amer. F. trop. Med. 24 , I89.

Rees, C. W., Bozicevich, J., Reardon, L. V. \& Jones, F. (1942). Amer. F. trop. Med. 22, 581.

Reeves, R. E., Schweinfurth, D. I. \& Frye, W. W. (I960). Amer. F. Hyg. 72, 2 I I. 
Seaman, G. R. (1963). Ann. N.Y. Acad. Sci. 102, 717.

Shaffer, J. G. \& Frye, W. W. (1948), Amer. F. Hyg. 47, 2 I 4.

Shaffer, J. G., Key, I. D. \& McDade, J. J. (1960). Bact. Proc. p. 58.

Shaffer, J. G. \& Sienkiewicz, H. S. (1952). Science, 116, 306.

Welch, C. S., Wakefield, E. G. \& Adams, M. (1936). Arch. intern. Med. 58, 1095.

Williams, P. P., Davis, R. E., Doetsch, R. N. \& Gutierrez, J. (196r). Appl. Microbiol. 9, 405.

Williams, P. P., Gutierrez, J. \& Davis, R. E. (1963). Appl. Microbiol. I1, 260.

\section{The nutrition of the micro-aerophilic pathogen Actinomyces israelii} By J. W. Porteous, Department of Biological Chemistry, Marischal College, University of Aberdeen

Micro-organisms have become well-established tools for research in the field of nutrition for reasons which are on the one hand of a purely technical and on the other of a biological nature. Technically micro-organisms are generally more readily grown in well-defined environmental conditions, their 'diet' is more readily controlled, the organisms themselves more readily handled and analysed than other biological forms. In biological terms micro-organisms offer the advantages of a relatively simple undifferentiated cell structure and, within the minute volume of a single cell, a large selection if not all of the biochemical activities typical of highly differentiated organisms such as plants and animals. Moreover, many microorganisms have been shown to respond to changes in environmental conditions through feedback mechanisms (including inhibition, induction and repression mechanisms) which are now well documented (Frisch, I96r; Riley \& Pardee, 1962) and some of which offer a partial explanation of metabolic regulation in organisms of greater cellular and organ complexity (Krebs, 1956; Knox, Auerbach \& Lin, I956; Wolstenholme \& O'Connor, 1959; Frisch, 196r; Allen, 1962; Weber, 1963; Pontecorvo, 1963). The fairly ready isolation of mutant micro-organisms derived from parent cells with known activities has helped in the elucidation of some aspects of intracellular control of metabolism (e.g. Jacob \& Monod, I96r; Monod \& Jacob, I96I), promoted inquiry into the detailed structure of genes (Demerec \& Hartman, I959; Pontecorvo, 1963) and helped to elucidate metabolic pathways and nutritional patterns (Davis, 1955; DeBusk, 1956).

It is nevertheless as well to realize that relatively few genera of micro-organisms have been used in the acquisition of this detailed insight into various aspects of biochemistry. In almost every instance the nutritional requirements of the test organism have been relatively simple and were known before the other knowledge was or could be acquired (Lichstein, I960). It may therefore be of some interest to recall aspects of work with an organism whose nutritional requirements and metabolic activities were, until recently, unknown. The reasons for this lack of knowledge were of a purely technical nature; it is the prime purpose of this paper to outline the methods used in determining the nutritional requirements of this micro-organism. It remains to be seen whether the detailed biochemistry of the organism fits the tentative predictions made from a knowledge of its nutritional requirements and is consistent with that outlined for organisms which, generally speaking, survive on simpler nutrient media. 